\title{
Study on the Standardization of a Surveillance Culture Laboratory in Infection Control Fields
}

\author{
Chang-Eun Park ${ }^{1}$, Na-Yeon Jeong ${ }^{2}$, Min-Ji Yang ${ }^{3}$, Han-Wool Kim ${ }^{4}$, Sei-Ick Joo ${ }^{5}$, Keon-Han Kim ${ }^{6}$, \\ Hee-Kyung Seong, ${ }^{7}$ Yu-Yean Hwang ${ }^{8}$, Hyun-Mi Lim ${ }^{9}$, Jae-Cheol Son ${ }^{10}$, Sun-Han Yoon ${ }^{11}$, \\ Nam-Seob Yoon ${ }^{12}$, In-Ho Jang ${ }^{13}$ \\ ${ }^{1}$ Department of Biomedical Laboratory Science, Molecular Diagnostics Research Institute, Namseoul University, Cheonan, Korea \\ ${ }^{2}$ Infection Control Office, Samsung Medical Center, Seoul, Korea \\ ${ }^{3}$ Department of Laboratory Medicine, Seoul National University Hospital, Seoul, Korea \\ ${ }^{4}$ Infection Control Office, Pusan National University Hospital, Busan, Korea \\ ${ }^{5}$ Department of Biomedical Laboratory Science, Daejeon University, Daejeon, Korea \\ ${ }^{6}$ Department of Laboratory Medicine, Gangnam Severance Hospital, Seoul, Korea \\ Department of Biomedical Laboratory Science, Dong-Eui Institute of Technology, Busan, Korea \\ ${ }^{8}$ Department of Laboratory Medicine, Samsung Medical Center, Seoul, Korea \\ Department of Laboratory Medicine, Soonchunhyang University Hospital, Seoul, Korea \\ ${ }^{10}$ Department of Pulmonology, Chungbuk National University Hospital, Cheongju, Korea \\ ${ }^{11}$ Seoul Clinical Laboratories, Yongin, Korea \\ ${ }^{12}$ Department of Laboratory Medicine, Asan Medical Center, Seoul, Korea \\ ${ }^{13}$ Department of Biomedical Laboratory Science, Sangji University, Wonju, Korea
}

\section{감염관리 분야에서 감시배양검사의 표준화 연구}

\author{
박창은 ${ }^{1}$, 정나연 ${ }^{2}$, 양민지 ${ }^{3}$, 김한울 $^{4}$, 주세익 ${ }^{5}$, 김건한 $^{6}$, 성희경 $^{7}$, 황유연 ${ }^{8}$, 임현미 ${ }^{9}$, 손재철 $^{10}$, 윤선한 $^{11}$, \\ 윤남섭 ${ }^{12}$, 장인호 ${ }^{13}$ \\ ${ }^{1}$ 남서울대학교 임상병리학과,분자진단연구소, ${ }^{2}$ 삼성서울병원 감염관리실, ${ }^{3}$ 서울대학교병원 진단검사의학과, ${ }^{4}$ 부산대학교병원 감염관리실, \\ ${ }^{5}$ 대전대학교 임상병리학과, ${ }^{6}$ 강남세브란스병원 진단검사의학과, ${ }^{7}$ 동의과학대학교 임상병리과, ${ }^{8}$ 삼성서울병원 진단검사의학과, \\ 9순천향대학교서울병원 진단검사의학과, ${ }^{10}$ 충북대학교병원 호흡기내과, ${ }^{11}$ 서울의과학연구소, ${ }^{12}$ 서울아산병원 진단검사의학과, \\ ${ }^{13}$ 상지대학교 임상병리학과
}

\begin{abstract}
An essential measure to prevent healthcare-associated infections (HAl) is to develop a consistent system of surveillance, thereby promoting a reliable situation diagnosis to perform efficient control for the problem. Patient-to-patient transmission of pathogens within the hospital plays a substantial role in the epidemiology of HAls. Contamination of healthcare environments commonly occurs, including facilities surfaces (e.g., bed rails, bedside tables), drinking water, cooling tower water, endoscopic instruments, food, airborne, endotoxin test, sterile test and medical equipment, with pathogenic organisms. In addition, epidemiological analysis is performed by multi locus sequence tying, pulsed-field gel electrophoresis for active surveillance. Therefore, an environmental surveillance culture test for prevention improves patient safety and blocks infection agents. Effective infection control and increased safety are possible by controlling the national infection control system. In conclusion, this study contributes to an effective infection control system through the standardization of active surveillance culture laboratory and secure expertise as infection control specialist. The primary objective of the standardization is to improve the safety of the nation's healthcare system by reducing the rates of HAls.
\end{abstract}

Key words: Active surveillance, Airborne culture, Drinking water, Endotoxin, Healthcare associated infection

This is an Open Access article distributed under the terms of the Creative Commons Attribution Non-Commercial License (http://creativecommons.org/licenses/by-nc/4.0) which permits unrestricted non-commercial use, distribution, and reproduction in any medium, provided the original work is properly cited.
Corresponding author: Chang-Eun Park Department of Biomedical Laboratory Science, Molecular Diagnostics Research Institute, Namseoul University, 91 Daehak-ro, Seonghwan-eup, Seobuk-gu, Cheonan 31020 , Korea

Tel: 82-41-580-2722

Fax: 82-41-580-2932

E-mail: eun2777@hanmail.net

Received: June 2, 2018

Revised: June 10, 2018

Accepted: June 14, 2018 


\section{서 론}

병원감염의 문제를 해결하기 위해 근본 원인의 파악을 위해 감염관리 감시배양 검사를 시행한다. 최근 자료에서는 유행발생 시 효율적인 관리를 위한주요 요소는 크게 감시(surveillance)를 수행하는 조사(investigation)와 유행 대응조치(outbreak response)의 요인들인, 유행통제(outbreak control), 유행통지 (outbreak communication), 유행기록(outbreak documentation)의 긴밀한 협조체계에서 이루어져야 한다[1]. 이중 전담 조사자로서 우리나라에서는 임상병리사가 환경적 요인 (environmental component) [2,3] 및 진단 검사 요인(laboratory component) 부분에서 행위를 수행하는 것으로 여겨진다. 고도의 의료기술인 침습성 시술의 발달은 다양한 건강문제를 해 결하는데 크게 기여하고 있지만 한편으로는 의료관련감염의 발 생을 증가시키고 있다. 이에 따라, 각 의료기관에 근무하는 보건 의료인은 감염관리에 대한 중요성을 인지하고 감염관리지식과 기술을 습득하여 효과적인 감염관리를 수행할 수 있어야 한다. 병원 내 감염의 주요 요인은 환경 청결, 의료인접촉, 수술 및 창상 치료, 식품, 주사 및 수액, 카데터 및 내시경, 물, 공기, 방문객 접 촉, 다른 환자접촉, 환자 자신의 내인성 감염, 매개물(옷, 침구) 등이 있다 [4, 5].

병원감염을 일으킨 것으로 추정되는 요인 발견 시 해당 요인 에 대한 적절한 배양 검사를 통해 원인 균주 및 전파 경로를 파악 한다. 이를 통해 추가적인 전파를 예방하고 효과적인 환자관리 를 수행한다. 최근에는 우리나라를 포함한 전 세계적으로 뉴델 리 메탈로-베타락타마제(New Delhi metalo-beta-lactamase, $\mathrm{NDM}-1$ ) 등[6] 항균제 내성유전자를 포함하는 다제내성균 출 현 및 증가는 새로운 보건문제로 대두되고 있으며, 2011년부터 의료관련감염증 6종을 표본감시 대상 법정 감염병으로 지정하 고2017년부터는 VRSA (vancomycin-resistant Staphylococcus aureus), CRE (carbapenem-resistant Enterobacteriaceae), 다제내성균에 대한 표본감시를 실시하나 표본감시대상 기관에 따라 진단시스템이 제대로 구축되어 있지 않거나 진단기준이 다르게 적용되고 있어, 효율적인 국가적 감염감시 및 관리를 위 해서는 진단법 표준화 및 교육이 필요하다. 감염된 환자의 병실 이 동일한 세균에 의해 자주 오염되고, 병원균이 의료 환경에서 장기간 생존할 수 있으며, 의료인의 손이나 장갑의 오염 빈도와 병실 오염빈도가 연관성이 있고, 사람간 전파나 의료기기 매개 로 인한 집단감염이 발생하고, 감염환자가 입원한 병실의 환자 가 동일한 병원균에 의한 정착이 흔하고, 병실을 청결하게 하면 감염률이 낮아지며, 소독을 잘하면 감염률이 낮아진다[7]. 이에
환자로부터 분리된 균과 환경에서 분리된 오염균의 상관분석에 서는 연관성이 높은 것으로 알려져 있다[8]. 병원환경 관리에서 의 미생물검사실의 역할은 의료관련감염 및 주요 내성세균의 감시, 원내 집단감염 발생 시 역학조사, 다제내성균의 보균자감 시 등 감염관리에 중요한 역할을 수행해 왔으며 환경관리를 위 한 감시배양도 시행하고 있다. 유행이 발생했을 때 원인을 찾기 위해 역학조사의 한 부분으로 미생물 검사를 시행하거나, 오염 된 표면의 오염 정도와 청결도를 평가하기 위해 미생물 검사를 시행하여야 한다[9]. 물, 환경표면의 검사는 비교할 만한 표준 검사방법이 있어야 하고, 이에 대한 충분한 기술이 있어야 하며, 배양 방법에 따른 적절한 장비나 배지 및 기술이 필요하다. 또한 미생물의 공기오염 측정을 위해서는 대용량 공기 채집기를 이 용하고, 수질오염을 평가하기 위해서는 적절한 증식 배지와 배 양 조건을 선택해야 한다. 또한 경우에 따라서는 환경에서 배양 된 세균과 환자 검체에서 배양된 세균의 비교가 유용할 수 있으 며, 가능하다면 균종 수준까지 분석해야 한다. 이렇게 감염원을 규명하는 것은 유행발생시 감염원의 전파경로를 파악하고 통제 를 위해 상대적으로 중요하게 강조되는 것으로 알려져 있다 [10]. 이에 미국 질병통제예방센터(center for disease control and prevention, $\mathrm{CDC}$ )는 환경관리의 평가수준을 기본(level I) 과 심화(level II)로 나누었으며, level II에 적용하는 행위의 직 접관찰, 미생물 배양검사, 형광표지, ATP 측정 같은 평가방법에 대해 제한점을 고려하여 평가방법을 선택하고 있다[11]. 미생 물 배양검사는 환경의 청결도를 평가하거나 환경에 존재하는 병원균을 검출하기 위해 흔히 고려되는 방법이나, 표준화된 방 법과 해석에 대한 합의가 부족하고, 시간과 자원이 많이 드는 제 한점이 있다. 또한 환경배양검사(수질검사, 공기배양검사, 무균 실 검사 등)가 필요한 경우는 역학조사에 근거해 의료진과 건강 상의 연관성이 있을 때, 배양결과가 감염관리 중재에 영향을 미 칠 수 있기 때문이다. 따라서 목표로 하는 세균에 맞추어 특수한 검체 수집방법을 제시하고 감시배양을 수행해야 실효성 있는 감염관리를 할 수 있으며 감염관리 분야에서 감시배양검사법 표준화에 따라 진단시스템이 제대로 구축된 국가적 감시 및 관 리를 위해서는 검사법의 표준화가 요구된다. 이에 본 연구는 표 준화된 감염감시배양검사의 확립과 의료기관에서 발생하는 의 료관련감염 중 임상병리사의 업무인, 환경감시배양검사를 숙 지시키고 업무 관리를 위한 자료로 활용하며 감염예방관리료 수가 산출을 위한 근거자료를 제공하고자 한다. 


\section{본 론}

\section{1. 검체의 채취 및 취급요령}

환경감시 배양용 검체 채취방법에 있어서는 검체 채취 시에 는 개인보호구(가운, 장갑, 마스크, 보호안경 등)를 착용하고 채 취하도록 한다. 그리고 냉각탑수의 균 배양은 레지오넬라균 (Legionella)이 $1,000 \mathrm{CFU} / \mathrm{mL}$ 이상 검출 시 감염의 위험이 높 으므로 즉시 조치를 취한다. 수돗물의 균 배양에서는 멸균통에 $1 \mathrm{~L}$ 정도의 물을 수거하고 수도꼭지 내부를 면봉으로 채취하고 수돗물 5 10 mL를 받아서 검사한다.

\section{2. 유행(outbreak) 조사와 분자역학 방법}

Repetitive extragenic palindromic sequence based PCR (REP-PCR)[12]과 enterobacterial repetitive infrequent consensus sequence based PCR (ERIC-PCR)은 원핵세포집 단 내에서도 다양하게 분포하고 있는 짧은 길이의 반복성의 염 기서열에 대해서 $\mathrm{PCR}$ 을 적용하여 유전자 수준의 다양성에 근 거하여 균주 상호간의 감별이 가능하며 이들 기법의 감별능력 은 기존의 PCR 기법보다 우수하다. 세균의 계통균주(strain)를 구별하기 위한 방법으로는 유전학적인 특성을 이용한 plasmid analysis, restriction endonuclease analysis, multilocus enzyme electrophoresis (MLEE), multilocus sequence tying (MLST) [13], pulsed-field gel electrophoresis (PFGE) [14, 15], amplified fragment length polymorphism (AFLP), repetitive sequence-based PCR (rep-PCR) 분석법 등이 있 으며 종의 특성에 따라 적용하고 있으며 분석의 과정은 다음과 같다(Figure 1). 특히, MLST에서는 다양한 데이터베이스의 일 치도 활용이 중요한 평가를 받고 있다(Table 1).

따라서 유행이 발생하였을 경우, 혹은 예방을 위해 후향적으 로 유행기간 수집된 균주들을 대상으로 분자 역학적 분석을 실 시하는 경우, 현재와 미래에서 공통으로 사용할 하나의 아형 결 정 방법을 선택해야 한다[16]. 이 결정에서 고려해야하는 방법 들의 특성들은 형 결정력(typeability), 재현성(reproducibility), 안정성(stability), 식별력(discriminatory power), 그리고 역 학적 일치도(epidemiological concordance), 그리고 실용성 (practicality) 등이다.

\section{3. 각 분야별 수질검사}

시료채취는 멸균된 1회용 tube에 5 10 mL를 무균적 조작 으로 다루고, 검체는 내독소가 없는 멸균용기에 채취한다. 채취 한 검체는 30 분 이내에 접종하며 2 시간이상 지체시 냉장보관하 며 24시간을 초과해서는 안 된다[17]. 항암제, 조영제, 제조수,

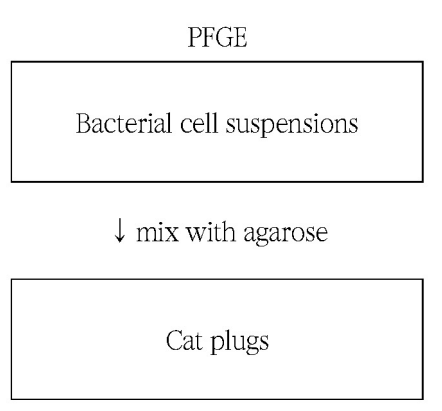

$\downarrow$ chemical lysis and washing

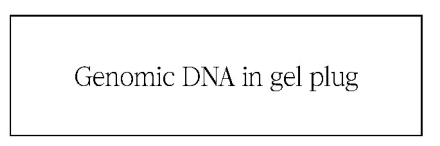

$\downarrow$ restriction enzyme

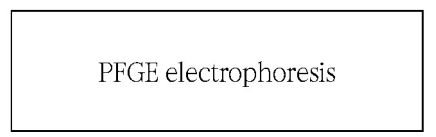

$\downarrow$ gel image documentation

Data analysis
MLST

Allelic profiles (7 categorical characters)

$\downarrow$ amplify of sequence

Analysis of MLST data
(Install plugin and choose organism from MLST
database)

$\downarrow$ import sequence

(Automatic download of genes, triming, positions, alleles, and MLST type)

$\downarrow$ match alleles

Sequences types are automatically created for housekeeping genes

$\downarrow$ figure outing

Calculated dendrograms, clonal complexes, minimum spaning trees, partitionings, statistics
Figure 1. Scheme of pulsed-field gel electrophoresis (PFGE) and multi locus sequence tying (MLST) analysis workflow. 
Table 1. Various databases and tools using web site

\begin{tabular}{|c|c|}
\hline Tool name & Web address \\
\hline BacMap & http://bacmap.wishartlab.com \\
\hline BIGSdb & http://pubmlst.org/software/database/bigsdb \\
\hline Centre for genomic epidemiology & http://www.genomicepidemiology.org \\
\hline CRISPRs web server & http://crispr.i2bc.paris-saclay.fr/ \\
\hline ENA & http://www.ebi.ac.uk/ena \\
\hline EnsemblBacteria & http://bacteria.ensembl.org/index.html \\
\hline GenBank & http://www.ncbi.nlm.nih.gov/genbank \\
\hline Genomes online & http://www.genomesonline.org \\
\hline GMI & http://www.globalmicrobialidentifier.org \\
\hline IMG & http://img.jgi.doe.gov \\
\hline Institut Pasteur MLST databases & http://www.pasteur.fr/mlst \\
\hline Microbial genome database for comparative analysis & http://mbgd.genome.ad.jp \\
\hline MLST Databases at the ERI, UCC & http://mlst.ucc.ie \\
\hline MLST homepage & http://www.MLST.net \\
\hline Molecular biology database collection & http://www.oxfordjournals.org/nar/database/a \\
\hline MLVA web service & http://bacterial-genotyping.igmors.u-psud.fr \\
\hline MYSQL 4.1 & http://www.mysql.com \\
\hline NCBI Genome & http://www.ncbi.nlm.nih.gov/genome \\
\hline PATRIC & http://patricbrc.org \\
\hline PHP & http://www.php.net \\
\hline PubMLST & http://pubmlst.org \\
\hline PubMLST database collection & http://pubmlst.org/databases.shtml \\
\hline rMLST on PubMLST & http://pubmlst.org/rmlst \\
\hline SRA & http://www.ncbi.nlm.nih.gov/sra \\
\hline The Microorganisms Tandem Repeats Database & http://minisatellites.u-psud.fr \\
\hline UCSC Microbial Genome Browser & http://microbes.ucsc.edu \\
\hline Xbase & http://www.xbase.ac.uk \\
\hline
\end{tabular}

치과용수[18]는 생물학적 안전상자(biosafety cabinet, BSC) 내에서 $1 \mathrm{~mL}$ 주사기를 이용하여 검체 $1 \mathrm{~mL}$ 를 tryptic soy agar (TSA), thioglycollate broth (TB)에 접종하고 $35 \sim 37^{\circ} \mathrm{C}$ 에서 2 주간 배양한다. 이때 배양 양성시, TB의 1 2방울을 혈액우무 배자에 계대배양하여 미생물동정검사를 수행한다.

정성적 배양검사에서는 biosafety cabinet (BSC)내에서 검 체 0.2 0.5 mL를 muller-hinton agar (MHA) 또는 TSA에 골 고루 펴서 접종 후충분히 건조시키는 도말평판법(spread plate technique, SPT)을 사용하거나 배지 $15 \sim 20 \mathrm{~mL}$ 에 검체 $1 \mathrm{~mL}$ 을 첨가하여 배양하는 주입평판법(pour plate technique, $\mathrm{PPT}$ )을 사용한다. 이때 $45^{\circ} \mathrm{C}$ 이하에서 15 분을 넘기지 말아야 한다. 이후 $\mathrm{CO}_{2}$ 배양기에서 $35 \sim 37^{\circ} \mathrm{C}$ 에서 2일간 배양한다. 또 한 trypton glucose extract agar (TGEA)나 Reasoner's agar No 2 (R2A) 배지를 사용할 경우는 $17 \sim 23^{\circ} \mathrm{C}$ 에서 7일간 배양하 여 보고한다.

정량적 배양검사에서는 $100 \mu \mathrm{L}$ 또는 $1,000 \mu \mathrm{L}$ 을 각각의 배 지에 4 way streaking으로 접종하고 $35 \sim 37^{\circ} \mathrm{C}$ 에서 48 시간 배 양 후 자란 집락수를 센다. 이때 각각 두 배지의 집락숫자가 다르 면 다시 재검하며 혈액우무배지(blood agar plate, BAP)나 초 콜릿배지(chocolate agar, $\mathrm{CA}$ )에서 집락이 퍼져 자리기 때문에 집락 수 계산이 어렵다. 최근에는 건조필름인 Petrifilm ${ }^{\mathrm{TM}}$ plates (3M, USA) 배지를 이용한 미생물 검사법을 통해 신속하 게 검사를 수행한다. 결과보고 및 판정기준에 있어서는 원내제 조 약물은 배양 후 7일에 중간보고와 14일에 최종 보고한다. 7 일 배양 후 자란 것이 없다면 "No growth after 7 days"로 중간 보고하며, 14 일 배양 후에도 자란 것이 없다면 "No growth after 14 days"로 최종 보고한다.

정제수의 경우는 2 일 배양 후 최종 보고하며 자란 것이 없다 면 “<10 CFU/mL” 로 최종 보고하고, 자란 경우 20 집락 미만 이면 “(집락 수) $\mathrm{CFU} / \mathrm{mL}$ ”로 보고하고, 20 집락 이상이면 “>20 $\mathrm{CFU} / \mathrm{mL}$ ”로 보고한다.

투석용수의 판정기준은 일반세균의 허용한계는 100 $\mathrm{CFU} / \mathrm{mL}$ 미만이며, 결과이상시 일반세균이 $50 \mathrm{CFU} / \mathrm{mL}$ 이상 이면 재검을 실시한다. Glorieux 등(2012)에 따르면 표준 투석 수(standard dialysis fluid)에서 최대허용수준(maximum allowable level, MAL)은 $100 \mathrm{CFU} / \mathrm{mL}$ 미만이며, 활동수준 (action level, $\mathrm{AL}$ )은 $50 \mathrm{CFU} / \mathrm{mL}$ 로 규정하고 있다[19]. 초순수 투석수(ultrapure dialysis fluid)에서 MAL을 $0.1 \mathrm{CFU} / \mathrm{mL}$ 미만 
으로 규정하고 있다. 정도관리용으로 각 배지 제조 시 quality control $(\mathrm{QC})$ 용 배지를 만들어 $35^{\circ} \mathrm{C}$ 에서 48 시간 배양하여 균 이 증식하지 않음을 확인해야 한다.

\section{4. 내독소(endotoxin)검사}

내독소 검사는 투석용수(용수저장탱크, 용수공급 파이프) 및 투석액[20], 역삼투압방식 원수, 배관수, 투석기계 유입수를 대 상으로 시행한다. 내독소 검사는 겔 형성을 지표화하는 겔화법 (gel clot, GC), 탁도를 측정하는 비탁법(kinetic turbidimetric assay, KTA), 화학 발색을 측정하는 비색법(kinetic chromogenic assay, $\mathrm{KCA}$ ) 중에 한 가지를 택해 측정한다.

$\mathrm{GC}$ 방법에서는 각 시료마다 시험군과 대조군을 준비한다. 시료 $200 \mu \mathrm{L}$ 를 각 tube에 분주하고, limulus amoebocyte lysate (LAL) 시약을 $200 \mu \mathrm{L}$ 씩 분주한 후 $37^{\circ} \mathrm{C}$ 항온수조에서 1 시간 반응을 시킨 후, 단단한 응고를 보이면 양성, 약간의 겔 형 태, 흐를 정도의 겔 형태 등은 음성으로 확인한다[21, 22].

$\mathrm{KTA}$ 는 내독소와 LAL이 반응하여 응고원(coagulogen)이 응 고물(coagulin)로 겔화할 때 발생하는 반응의 탁도 변화를 405 $\mathrm{nm}$ 에서 광학분석장치에서 측정하는 것이며, $\mathrm{KCA}$ 는 효소반응 의 활성화 과정에 발색 기질을 더하여 발색을 유도하고 발색량 을 측정하는 것으로 발색량인 높을수록 내독소의 양이 증가함 을 알 수 있는 방법이다[23]. 이들의 결과판정으로는 허용한계 가 0.25 endotoxin unit $(\mathrm{EU}) / \mathrm{mL}$ 미만이며, 결과이상시 교정 한계는 $0.125 \mathrm{EU} / \mathrm{mL}$ 미만으로 규정한다. 표준 투석수 (standard dialysis fluid)에서 MAL은 $0.5 \mathrm{EU} / \mathrm{mL}$ 미만이며, 활 동수준은 $0.25 \mathrm{EU} / \mathrm{mL}$ 로 규정하고[19], 초순수 투석수(ultrapure dialysis fluid)의 MAL을 $0.03 \mathrm{EU} / \mathrm{mL}$ 미만으로 규정하고 있다. 결과 이상시 재검 후에도 동일한 결과라면 해당 부서에 바로 보 고하고 장비사용을 중단하고 문제 해결 후 재검을 실시하도록 한다.

\section{5. 냉각탑용수 검사}

수도 및 샤워기에서 멸균 면봉의 검체 채취방법은 냉수 및 온 수 채취 전에 먼저 시행해야한다. 수도꼭지의 망을 제거하거나 샤워기 헤드를 샤워기 몸체에서 분리하여 멸균면봉을 샤워기 헤드 안으로 넣고 3 4회 돌려서 내부의 침전물을 채취한다. 이 때 증류수 $1 \mathrm{~mL}$ 를 미리 넣어둔 멸균용기에 검체 면봉을 넣는다. 만일 멸균용기에 증류수를 넣어두지 않을 경우에는 검체 채취 시설의 물 $1 \mathrm{~mL}$ 를 멸균용기에 넣은 후 검체를 채취한 면봉을 넣 는다.

수도 또는 샤워기의 냉수 및 온수의 검체 채취방법은 수도꼭
지 또는 샤워기 꼭지를 냉수로 최대한 옮긴 후, 1 2분간 물을 그냥 흘려보낸 후, 무균 채수병에 $1 \mathrm{~L}$ 이상의 냉수를 받은 후, 온 도 및 잔류염소를 측정한다. 수도꼭지를 온수로 최대한 옮긴 후, $1 \sim 2$ 분간 물을 그냥 흘려보낸다. 무균 채수병에 $1 \mathrm{~L}$ 이상의 온수 를 받은 후, 온도 및 잔류염소를 측정한다.

냉각탑수 채취방법에서는 냉각탑이 가동될 때, 냉각탑 안에 있는 물을 무균 채수병에 $1 \mathrm{~L}$ 이상 채취하고 온도를 측정한다. 검 체는 채취한 후, 냉장 $\left(4 \sim 10^{\circ} \mathrm{C}\right)$ 상태로 24 시간 이내에 해당 실 험실에 수송되어야 하며, 수송된 검체는 $4^{\circ} \mathrm{C}$ 에 보관한다.

냉각탑수, 냉수 및 온수, 가습기물 등의 수질검체는 $1 \mathrm{~L}$ 를 0.2 또는 $0.45 \mu \mathrm{m}$ 여과지로 농축하고 멸균된 증류수 또는 여과의 여과액 $20 \mathrm{~mL}$ 에 여과지를 부유시켜 $50^{\circ} \mathrm{C}$ 에서 30 분간 열처리 후 부유액을 희석하여 각각의 $0.1 \mathrm{~mL}$ 씩 GVPC (glycine 또는 cefamandole vancomycin, polymyxin B, cyclohexamide) 및 BCYE (buffered charcoal yeast extract) 배지에 도말하고 $5 \% \mathrm{CO}_{2}$ 조건의 $35 \sim 37^{\circ} \mathrm{C}$ 배양기에서 3 10일간 배양하면서 관찰한다[24]. 면봉 검체는 검체 면봉이 담긴 멸균 증류수 $1 \mathrm{~mL}$ 을 $50^{\circ} \mathrm{C}$ 에서 30 분간 열처리하고 부유액을 희석하여 각각의 $0.1 \mathrm{~mL}$ 씩 GVPC 및 $\mathrm{BCYE}$ 배지에 도말하고 $5 \% \mathrm{CO}_{2} 35 \sim 37^{\circ} \mathrm{C}$ 배양기에서 3 10일간 배양하면서 관찰한다.

집락관찰에서는 배양된 집락들 중 육안으로 관찰하였을 때, 전체적으로 매끄럽고 볼록한 면을 나타내고 집락이 커지면 음 영이 사라지고 중앙과 전체가 불투명해지며, 해부현미경으로 관찰하였을 때 청색, 분홍, 또는 녹색의 음영이 관찰되는 집락을 레지오넬라균으로 의심하여 1차로 선별하며 Francisella tularensis, Bordetella pertussis, Nocardia asteroides 등도 $\mathrm{BCYE}$ 한천배지에서 배양되어 레지오넬라균과 구별하기 어려 운 균주이므로 동정에 유의해야 한다.

\section{6. 멸균확인검사(중앙공급실 등)}

Spordi ${ }^{\circledR}$ strip (3M Health Care, MN, USA) 또는 Attest ${ }^{\text {TM }}$ (3M Health Care)으로 중앙공급실에서 의뢰서와 함께 의뢰한 다. Spordi ${ }^{\circledR}$ strip NA008/NA010 biological indicators (Bacillus atrophaeus, Geobacillus stearothermophilus)와 Attest $^{\mathrm{TM}}$ 290, 1291, 1292 biological indicators (Geobacillus stearothermophilus)는 2 $24^{\circ} \mathrm{C}$ 에 보관해야 한다[25].

수기 검사의 경우에는 thioglycollate broth bottle에 검사대 상 및 날짜를 작성하고 장갑을 착용하고 배지 입구를 알코올램 프를 이용하여 소독한다. Spordi ${ }^{\circledR}$ Strip의 주변에 노출되지 않 도록 무균적으로 배지에 넣는다. Attest ${ }^{\mathrm{TM}}$ 의 경우는 검체의 뚜 껑을 열어 깨어진 유리 앰플을 버린 후 표지자가 심어져있는 종 
이를 알코올램프로 소독한 핀셋을 이용하여 무균적으로 채취하 여 배지에 넣는다. 이후 배지를 $35^{\circ} \mathrm{C}$ 배양기에서 24 시간 배양 하고 멸균이 잘 된 Spordi ${ }^{\mathrm{R}}$ strip 또는 Attest ${ }^{\mathrm{TM}}$ 는 배지가 맑고 투명하게 보인다. 확인시험으로는 배지가 투명하지 않고 혼탁 하게 변했다면 계대 배양해서 균종을 확인하여 오염여부를 확 인해야 한다. 대조균주는 확인시험을 수행할 필요가 없다. Thioglycollate broth 1 2방울을 혈액우무배지에 순수배양 하고 자란 집락을 그람 염색하여 그람 양성 막대균이 아닌 경우 는 검사 과정의 오염일 가능성이 높음으로 재검을 원칙으로 한 다. 그러나 그람 염색 결과가 그람양성 막대균인 경우 미생물 동 정 장비에 동정검사로 최종 확인 한다. 미생물 동정 장비에서 Bacillus subtilis 또는 Bacillus atrophaeus 외에 다른 균이 동 정된 경우는 역시 검사 과정의 오염일 가능성이 높음으로 재검 을 원칙으로 하고 "No growth" 는 $35^{\circ} \mathrm{C}$ 배양기에서 1 주일 동 안 배양한 후, 최종 “No growth” 로 보고한다.

Attest ${ }^{\mathrm{TM}}$ 는 생물학적 지표를 배양 중 형광물질로 검출하는 배 양액의 색변화를 통해 관찰하는 방법으로 고압증기멸균에서는 안의 vial을 깨어 $56^{\circ} \mathrm{C}$ 배양기에 넣어 48 시간 배양하여 확인하 거나, 자동판독기를 사용하여 스팀멸균[26], 포르말린용 $57 \pm 2^{\circ} \mathrm{C}$ 에서 1 3시간 배양 후에 판독하며 이때 색이 보라색 유무를 확 인하며 균이 자라면 황색으로 나타난다. 그러나 에틸렌 옥사이 드(ethylene oxide, $\mathrm{EO}$ ) 가스 멸균에서는 안의 vial을 깨어 $35^{\circ} \mathrm{C}$ 배양기에 넣어 48 시간 배양하거나 자동판독기를 사용 $\left(37 \pm 2^{\circ} \mathrm{C}\right.$ 4시간 배양 후)하여 판독하며 연두색 유무로 확인하 며 균이 자라면 황색으로 나타난다. 균이 자라서 Bacillus subtilis 또는 Bacillus atrophaeus 가 동정이 되면 각 부서 파트 장에게 구두로 보고하여 반출된 물품이 신속하게 수거될 수 있
도록 조치한다[27].

\section{7. 내시경감시 검사}

내시경적 역행성 담췌관 조영술(Endoscopic retrograde cholangio-pancreatography, ERCP)의 경우에 세척이 끝난 내시경을 멸균된 장갑을 착용한 후, 멸균된 brush로 channel의 각각 내벽을 솔질한다. 샘플 채취 개수에 맞춰 $50 \mathrm{~mL}$ 멸균주사 기에 증류수를 채워 준비하고, 각 channel에 증류수를 주입하 여 관류액을 멸균된 $50 \mathrm{~mL}$ conical tube로 받는다. 주사기에 바 람을 채워 다시 한 번 공기로 관류하여 샘플 채취가 어려운 것을 대비하여 관류액을 최대한으로 받는다[28, 29].

기구 당 적어도 4 5개의 샘플 채취를 하고, 채취한 관류액은 뚜껑을 세지 않도록 잘 잠근다. 채취한 샘플은 약 2 분간 진탕 혼 합하는데 이때, 전용 솔이 같이 들어 있는 경우는 멸균 forcep으 로 제거한다. 그런 후 brain heart infusion broth (BHIB)의 5 $\mathrm{mL}$ 에 혼합한 샘플 $100 \mu \mathrm{L}$ 를 접종하고, 그람음성 특정균을 보기 위해서는 MacConkey broth로 대체하여 진행한다. 관류액 $100 \mu \mathrm{L}$ 취한 후, 남은 여액은 모두 필터한 후 멸균된 forcep으로 필터 종이를 들어 혈액우무배지에 접종하여 $37^{\circ} \mathrm{C}$ 배양기에서 $18 \sim 24$ 시간 배양한다. 한편, $100 \mu \mathrm{L}$ 을 접종한 $\mathrm{BHIB}$ 는 $37^{\circ} \mathrm{C}$ 배 양기에 24시간 배양 후각 배지에 접종하며, 필터 접종한 혈액우 무배지의 집락 수를 총 CFU/duodenoscope로 계산한다. $\mathrm{BHIB}$ 에 증균 배양한 결과도 고려하여 결과 보고하고 자란 균은 그람염색을 한다. 고-관심주요군(High-concern, $\mathrm{HC}$ ) 세균의 경우는 자동화 장비로 빠른 결과를 보고한다. 일반적으로 $\mathrm{HC}$ 세균에는 재검사를 시행하는 경우는 Staphylococcus aureus, Enterococcus spp., Streptococcus spp., viridians group,

Table 2. Overview of guidelines on microbial surveillance of endoscopes

\begin{tabular}{|c|c|c|c|c|c|c|}
\hline $\begin{array}{l}\text { Sampling } \\
\text { technique }\end{array}$ & $\begin{array}{c}\text { Sampling } \\
\text { volume, (mL) }\end{array}$ & $\begin{array}{l}\text { Volume used } \\
\text { for culture }\end{array}$ & $\begin{array}{l}\text { Culture } \\
\text { medium }\end{array}$ & $\begin{array}{l}\text { Incubation } \\
\text { temperature }\left({ }^{\circ} \mathrm{C}\right)\end{array}$ & $\begin{array}{l}\text { Duration of } \\
\text { incubation(d) }\end{array}$ & $\begin{array}{l}\text { Criterion of } \\
\text { acceptance }\end{array}$ \\
\hline $\begin{array}{l}\text { Flushing with sterile } \\
\text { saline }\end{array}$ & 20 per channel & $20 \mathrm{~mL}$ & - & - & - & Unclear \\
\hline $\begin{array}{l}\text { Flushing with sterile } \\
\text { saline+brush }\end{array}$ & 20 per channel & $20 \mathrm{~mL}$ & - & - & - & $<20$ CFU/channel \\
\hline $\begin{array}{l}\text { Flushing with sterile } \\
\text { tensioactive fluid }\end{array}$ & $100 \sim 200$ & $100 \sim 200 \mathrm{~mL}$ & $\begin{array}{c}\text { Non-selective } \\
\text { agar }\end{array}$ & 30 & 5 & $\begin{array}{l}<25 \text { CFU; no } \\
\text { indicator } \mathrm{MO}\end{array}$ \\
\hline $\begin{array}{l}\text { Flushing with sterile } \\
\text { saline }\end{array}$ & 20 per channel & $1 \mathrm{~mL}$ & $\begin{array}{c}\text { Non-selective } \\
\text { agar }\end{array}$ & 30 & 2 & $\begin{array}{l}<20 \text { CFU; no } \\
\text { indicator } \mathrm{MO}\end{array}$ \\
\hline $\begin{array}{l}\text { Flushing with sterile } \\
\text { water or saline+brush }\end{array}$ & 10 per channel & $\begin{array}{l}100 \mu \mathrm{L} \text { (after } \\
\text { centrifuagtion) }\end{array}$ & 2 blood agars & $\begin{array}{l}28 \\
35\end{array}$ & 7 & $\begin{array}{l}<10 \text { CFU; no } \\
\text { indicator } \mathrm{MO}\end{array}$ \\
\hline $\begin{array}{l}\text { Flushing with sterile } \\
\text { water+brush }\end{array}$ & 10 & $100 \mu \mathrm{L}$ & $\begin{array}{l}\text { Blood agar, } \\
\text { Sabouraud agar }\end{array}$ & $\begin{array}{l}37 \\
30\end{array}$ & $\begin{array}{l}2 \\
5\end{array}$ & $<20$ CFU/0.1 mL \\
\hline $\begin{array}{l}\text { Flushing with sterile } \\
\text { saline+brush }\end{array}$ & - & - & - & - & - & $\begin{array}{c}\text { No vegetative } \\
\text { bacteria }\end{array}$ \\
\hline
\end{tabular}

Abbreviations: MO, microorganisms; CFU, colony-forming units; -, not mentioned. Sources: references 28 and 32. 
Pseudomonas aeruginosa, Klebsiella spp., Salmonella spp., Shigellaspp., 기타 장내 그람 음성 세균이 동정되었을 경 우를 의미하고, 저-관심주요군(Low-concern, LC) 세균은 coagulase-negative Staphylococci (CNS), Micrococci, Diptheroids, Bacillus spp,. 기타 그람양성 막대균을 의미하고 $10 \mathrm{CFU} /$ duodenoscope 이상이면 재검사를 시행한다[30, 31]. 제한점으로는 모든 미생물에 대한 검출에 제한이 있으며, 내시 경 기구마다의 특징을 고려하여 배양검사를 진행한다. 또한 필 요한 경우에는 양성으로 보고되는 균주는 유행발생시 원인체의 확인을 위해 균주를 보관해야 한다. 최근 보고된 내시경의 검체 채취기술, 채취량, 배양방법, 결과해석에 대한 가이드라인을 통 해 유럽등지에서 적용하고 있다(Table 2)[28, 32].

\section{8. 집단 급식시설 위생 검사}

식품용수 및 음용수[33], 얼음, 음료의 경우[34], 일반 세균검 사에서는 채취 tube의 입구가 오염되지 않도록 뚜껑을 연 후, 무 균적으로 채취한다. 접종 방법으로는 주입도말법으로 멸균된 $\mathrm{TSA}$ 를 $45^{\circ} \mathrm{C}$ 정도로 식힌 후 시료 $1 \mathrm{~mL}$ 를 무균적으로 취하여 $\mathrm{TSA}$ 에 $15 \mathrm{~mL}$ 를 분주하고 페트리접시 뚜껑에 부착하지 않도록 주의하면서 회전하여 검체와 배지를 잘 혼합하여 응고시킨다. 이때 확산집락의 발생을 억제하기 위하여 다시 TSA의 $3 \sim 5 \mathrm{~mL}$ 를 가하여 중첩시키고 20 분내에 수행한다. 이후 $35^{\circ} \mathrm{C}$ 배양기에 서 48시간 배양하여 집락수를 계산하고 이후 1 주일 까지 실온 에 보관하면서 1 주일이 되었을 때 집락수를 최종 보고한다.

대장균군 검사에서는 시료 $0.1 \mathrm{~mL}$ 을 MacConkey agar 또는 선택도가 높은 배지에 접종하고 $35^{\circ} \mathrm{C}$ 배양기에서 48 시간 배양 한 후, 균이 자라면 그람염색과 계대배양을 하고 미생물 동정검 사를 실시하나 균이 자라지 않으면 1주일간 실온에 방치하면서 배지를 관찰한다[35].

조리도구 및 조리원의 손에서 검사진행은 현장을 방문하여 시행한다. 검사장소에 도착하면 대상 이름을 적고 검사 준비를 한다. 채취 때 glove를 착용하고 멸균 생리식염수에 수송용 채 취면봉 적신 후 검사대상 표면을 꼼꼼하게 한다. 모든 검체 채취 가 끝나면 미생물검사실에서 검사항목에 맞는 배지에 접종한 다. 배지를 $35^{\circ} \mathrm{C}$ 배양기에서 48 시간 배양하여 균이 자라면 그 람염색과 계대배양을 하고 미생물 동정검사를 실시한다. 균이 자라지 않으면 1 주일간 실온에 방치하면서 배지를 관찰한다.

결과 보고에서는 식품용수 및 음용수[36], 얼음, 음료의 일반 세균은 $100 \mathrm{CFU} / \mathrm{mL}$ 미만이고, 대장균군은 $50 \mathrm{~mL}$ 중 불검출로 보고하고, 조리원 손은 황색 포도알균 불검출, 조리 기구는 식중 독 위험균 불검출로 보고한다. 결과 이상이 발생시에는 음용수
에서 기준치 이상의 균, 또는 대장균이 검출되거나 시료에서 식 중독 위험균이 검출 될 경우에는 해당 조리장의 위생 상태를 재 점검한 후 재검을 실시한다. 이때 주의할 사항은 시료채취용 조 리도구 준비 시 깨끗이 세척 후 완전 건조된 상태에서 처리한다. 또한 조리원의 손을 검사할 경우에는 덜 건조된 소독제 및 물로 인한 환경균이 자랄 가능성이 크므로 손 위생 후 완전 건조된 손 을 검사한다. 정도관리용 배지로는 $\mathrm{TSA}$ 를 제조하여 $35^{\circ} \mathrm{C}$ 에서 48시간 배양 후, 세균의 증식이 없음을 확인한다. 또한 Cronobactergenus (Enterobacter sakazakii)는 주로 멸균되 지 않은 조제분유(powdered infant formula, PIF)로 인해 발생 하기에 주의해야 한다[37].

\section{9. 공기배양검사}

검사대상은 공기 전파 진균 감염 집단 발생하거나[38], 고위 험 환자군의 병실에 근접한 곳에서 건축 작업이 이루어질 때, HEPA (high efficiency particulate air) 공조가 이루어지는 방 을 처음 사용할 때, 골수 이식환자, 항암요법환자 입원실 HEPA 공조방에서 이루어진다[39]. 무균 및 고위험구역인 무균실, 수 술실은 500 1,000 L를 채취하는 것을 원칙으로 한다[40].

부유세균 검사에서는 검체 채취를 위해서는 장비와 샘플 그 리드의 위생 상태를 확인해야 하며, 샘플 그리드를 장착 또는 탈 착할 때 표면의 구멍에 손이 닿지 않도록 주의해야한다. 배지는 실험하는 장소와 검출하고자 하는 미생물의 유형에 따라 선택 한다. 직경 $90 \mathrm{~mm}$ 배양 접시에 부어져 있는 배지는 깊이가 최소 $2.5 \mathrm{~mm}$ 정도이며, 표면은 평평하게 만들어져야 한다. 너무 건 조되어 있거나 물방울이 맺혀 있으면 사용하지 않는 것이 좋다 [41].

또한 검체 채취하는 동안에 불필요한 동작은 피하고 장비 앞 으로 지나가거나 기침하지 않도록 한다. 오염도가 낮은 지역부 터 검사를 실시하며, 장비를 평편한 표면 위(작업대나 테이블) 에 수평, 수직 또는 삼각대에 장착한 형태로 올려놓는다. 또한 공기 채집기에 배지를 끼우고 채취하고자 하는 지점에서 20 분 이상 간격으로 3 회 연속 측정한다. 실험 전 배지는 물기가 생기 지 않게 주의하며, 배지의 온도를 시험장소 온도와 평형화시키 는 것이 바람직하다. 최종적으로 날짜와 시간, 검체 채취장소를 배양접시에 기록한다. 결과판정은 의료기관내의 공기 오염도 기준을 총 부유세균 $\left(\mathrm{CFU} / \mathrm{m}^{3}\right) 800$ 이하로 규정하고 있다[42].

낙하세균의 검사에서는 50 이하(청정), 50 75(요주의도), 75(제한도), $75 ~ 100$ (고도)로 분류한다. 낙하균의 측정방법에 있어서는 측정하고자 하는 구역을 모서리와 중앙부까지 5 곳을 설정하여 준비한 평판배지를 한 곳에 한 장씩 또는 2장씩을 놓 
고 노출을 동일 시험 장소에 평판배지를 놓고 뚜껑을 열어 공기 중에 노출하여 방치한다[43]. 노출시간은 5분 간격으로 1 시간 동안 수회 방치한다. 방치는 15 분 수행하고 1 시간 동안 같은 방 법으로 수회 진행한다. 배지에 낙하된 것을 $35^{\circ} \mathrm{C}$ 배양기에서 4 7 일간 배양하고 색소 생성균인 경우는 $20 \sim 25^{\circ} \mathrm{C}$ 배양기에서 48시간 동안 배양하여 집락수를 계산한다. 결과보고에서는 세 균 및 진균 검출을 위한 공기 채취량 당 집락수를 $\mathrm{CFU} / \mathrm{L}$ 또는 $\mathrm{CFU} / 15^{\prime}(90 \mathrm{~mm})$ 로 표기한다. 멸균 지역은 $<10 \mathrm{CFU} / 1,000 \mathrm{~L}$, 관리 지역은 $<30 \mathrm{CFU} / 1,000 \mathrm{~L}$, 일반 지역은 $<50 \mathrm{CFU} /$ $1,000 \mathrm{~L}$ 로 규정하고 있다.

\section{결 론}

본 연구를 통해 국내의 감염관리 분야의 감시배양 검사의 국 내 기술 확립 및 표준화 기법을 확보하여 중소병원에 보급하고 감염관리 분야의 업무역량의 강화를 추구하고자 한다. 한편 감 염관리 수가 지원 등의 파급효과에 역할을 도모하고자 한다. 나 아가 국민 보건 및 삶의 질 향상과 감염관리 분야의 근본적인 기 술보급과 실효성 있는 감염관리 분야의 사회적 기여를 하고자 한다. 또한 국내 고유의 감시배양 검사의 근거자료 확보를 통해 의료관련 감염으로 인한 손실을 최소화하기 위한 정책 수립의 기초자료로 활용할 것이며, 국내 중소병원의 의료관련 감염관 리 문제점 및 유행에서의 원인 파악 및 개선방안을 도출하고 국 내 현실에 맞는 국가 차원의 구체적인 실무 의료관련감염관리 전략 개발의 표준화 기법을 제시함으로써, 의료관련감염관리 지침에 포함되는 기법 개발, 교육, 홍보 분야에서 보다 체계적이 고 연속성 있는 감염관리 사업을 추진하는 데 본 과제의 결과가 활용될 수 있을 것으로 사료된다. 감염감시 시스템은 유행발생 의 역학적 조사 후의 검증, 병원환경오염과 병원 감염의 상관분 석, 위험요인의 효과적인 방역활동 평가, 감염관리 행위의 질 평 가를 위해 구축되어져야 할 것이다[44].

검체 채취 기구 및 용기는 검체의 종류, 형상, 용기 - 포장 등 이 다양하므로 검체의 수거 목적에 적절한 기구 및 용기를 준비 하고 운반, 세척, 멸균에 편리한 것이어야 하며 미생물 검사를 위한 검체 채취의 기구용기 중 검체와 직접 접촉하는 부분은 반 드시 멸균 처리된 것을 사용해서 검사결과에 영향을 미치지 않 아야 한다[45].

최근 PFGE [46], RAPD, AFLP 등은 재현성에 문제점을 보였 으며, MLST는 재현성은 우수하나 각 특정유전자 염기서열 분 석방법으로 분석능력과 종에 제한이 있다는 단점이 있다. 이에 반해 rep-PCR법을 이용한 자동화 분석방법은 표준화 키트를
제공함에 따라 재현성 면에서 우수하며 무엇보다도 쉽고 빠르 게 분석결과를 확인할 수 있다는 장점이 있다.

유행이 반복적으로 발생하거나, 여러 지역에 걸쳐 발생할 경 우에는 분자 역학적 분석을 여러 검사실에서 진행할 수 있다. 만 약 각각의 검사실이 서로 다른 방법으로 아형을 결정한다면 이 유행의 역학적 특성을 분석하는데 있어 상호 연관성을 밝혀내 기 어려울 것이다[47].

투석용수(용수저장탱크, 용수공급 파이프) 및 투석액, 역삼 투수(reverse osmosis, R/O), 배관수, 투석기계 유입수, 원내 제조약물, 정제수, 치과 유니트 $\mathrm{R} / \mathrm{O}$ 수 및 각종 배관수, 항암제, 조영제에 대해서 주기적으로 철저한 관리가 필요하다.

내독소는 발열원(pyrogen)으로 체온중추를 자극해 강한 발 열작용을 일으키는 물질로 열에 안정하여 통상적인 멸균으로 활성을 잃지 않으므로 건열멸균 등으로 불활성화 시켜야 한다. 노출 시에는 발열과 백혈구감소증, 쇼크를 심하게는 패혈증까 지 일으킨다. 따라서 투석에 사용하는 물은 내독소 검사를 시행 해야 한다.

환경 수질의 검체 채취 범위는 증상발현 전 2일 이상 연속으 로 입원한 경력(중환자실 입원도 포함)이 있으면, 환자가 입원 한 병동의 화장실, 샤워실, 목욕실, 가습기, 병원의 물 저장 탱크, 냉각탑수(하절기에만 채취)에 대한 검체 채취 및 검사를 실시해 야 한다[48].

모든 멸균소독기는 정기적으로 생물학적 검사를 받아야 한 다. 검사시행 주기로는 건열멸균기를 사용할 때마다 의뢰하고, 스팀이나 ethylene oxide가스 및 포르말린 멸균은 신속처리장 비에서 결과가 양성이 나올 경우에 의뢰한다. 또한 멸균기 수리 후 재사용 시, 새로운 멸균기 도입 시에도 의뢰하여 3 회 배양검 사에서 음성을 확인 후 사용한다.

기구의 사용 전 미생물을 확인하는 단계로 전처리를 통한 정 성 및 정량검사를 목적에 맞게 시행한다[49]. 정량검사의 경우, 원심분리 또는 필터배양으로 진행하고, 증균 배양은 적절한 선 택배지를 사용하여 적은 양의 균을 검출하는데 사용된다. 내시 경 감시검사의 인증은 연 1회 검사를 준수하되, 유행 발생시 기 간을 조정하여 검사를 진행한다.

최근 Lien Cattoir 등[32]의 보고에서 내시경의 미생물 감시 에 대한 가이드라인을 제시하고 있는데 샘플 채취기술, 샘플 양, 배양을 위한 양, 배양 배지, 배양 온도, 배양 기간, 판독 결과 등에 대한 기준의 장단점이 변화하여 사용되고 있음을 알 수 있었다. 일부기관에서는 세균의 정량적인 측정보다 존재 유무를 확인하 는 비배양법으로 adenosine triphosphate bioluminescence assays를 활용하여 내시경 세척 후 확인용으로 사용하고 있다 
[50, 51]. 그러나 최근 내시경 모델에서 채취용기는 polytetrafluoroethylene (PTFE)를 사용하며, 검체를 채취할 경우, PULL $\mathrm{THRU}^{\mathrm{TM}}$ cleaning device (MEDIVATORS Inc, Minneapolis, $\mathrm{MN}, \mathrm{USA}$ )를 활용하여 멸균된 생리식염수 $10 \mathrm{~mL}$ 을 이용해 flush-brush-flush로 채취하는 방법이 회수율이 높은 것으로 권장한다. 또한 남아있는 검체를 진공펌프를 활용한 $0.45 \mu \mathrm{m}$ 막에서 회수하여 배양하거나 $100 \mu \mathrm{L}$ 의 검체를 TSA에 접종하여 $30^{\circ} \mathrm{C}$ 에서 7일간 배양하여 집락수를 보고하거나 질량분석기 (matrix-assisted laser desorption/ionization time-of-flight mass spectrometry, MALDI-TOF MS; Microflex LT, Bruker Daltonics, Bremen, Germany)를 통해 동정하는 방법을 권장 하고 있다[52, 53].

식품위생관련 사고발생 위험성이 높은 하절기에 식품 조리 도구의 위생관리 상태를 점검하기 위하여, 또는 집단 급식시설 의 식중독 의심사례 발생 시 원인을 추적하기 위하여 미생물 검 사를 시행한다. 식품용수 및 음용수, 얼음, 음료는 TSA를 사용하 고 조리도구, 조리원 손은 BAP, MacConkey agar, Salmonella Shigella agar (SS), thiosulfate citrate bile salts sucrose agar (TCBS)를 이용한다.

공기 중의 오염도를 측정하는 과정은 오염을 예방하기 위한 과정의 일환으로 현재의 오염상태와 위생 기준과, 조절방법을 검토하여 위험정도와 전체 위생 상태와 환경에 대한 정보를 제 공한다[54, 55].

결론적으로 본 연구를 통해 제시된 감염관리 임상병리사의 활동 감시를 위한 검사법들의 표준화를 구축하고 이에 따른 기 법들의 유용성 평가를 지속적으로 만들어가며, 감시배양검사 를 위한 실무 전문가들이 효과적으로 활용할 수 있을 것으로 보 인다. 향후에는 실무경험상 문제점에 대한 분석을 도출하고 활 용할 수 있는 기준이 되기를 바라며, 감염관리 업무의 체계가 구 축되어 원활한 업무의 과정이 이루어져 의료관련 감염 예방 및 관리 향상과 국민 보건 증진의 기틀을 마련할 수 있을 것으로 기 대한다.

\section{요 약}

의료 관련 감염을 예방하기 위한 필수적 방법은 일관성이 있 는 감염감시 시스템을 구축하고 효율적인 감시 통제를 수행하 기 위해 신뢰할 수 있는 상황에 대해 진단을 향상시켜나가는 것 이다. 또한 의료 종사자의 손과 의복 및 장비는 환자 관리 및 환 경과 접촉하여 병원체가 오염되는 요인이다. 병원체를 가진 시 설 표면(예: 침대 레일, 침대 옆 탁자), 음용수, 냉각탑용수, 내시
경기구, 급식위생, 공기매개, 멸균검사, 내독소검사, 및 의료 장 비를 포함한 의료 환경의 오염은 일반적으로 발생한다. 또한 이 러한 감염원을 활동 감시를 통해 MLST, PFGE의 기법으로 역학 분석을 수행한다. 따라서 HAI 예방을 위한 환경 감시배양 검사 는 환자의 안전과 감염원의 차단을 향상시킬 뿐만 아니라 국가 의 감염관리 시스템을 통제하여 최적의 효율적인 감염관리 예 방을 가능케 하고 국가의 감염관리 시스템의 안전을 향상시킨 다. 결론적으로 감시배양 검사의 표준화를 통해 실효성 있는 감 염관리체계에 이바지하고 감염관리 전문인력으로서의 전문성 을 확보하고자 한다. 이를 통해 표준화 마련의 일차적인 목표는 의료관련 감염을 줄이고 국가적 의료관리 체계를 향상시키는데 있다.

Acknowledgements: This work was supported by the Korean Association Medical Technologist research fund (2017).

Conflict of interest: None

\section{REFERENCES}

1. Goodman RA, Buehler JW, Koplan JP. The epidemiologic field investigation: science and judgement in public health practice. Am J Epidemiol. 1990;132:9-16. http://dx.doi.org/10.1093/ oxford journals.aje. a115647.

2. Olmsted RN. Prevention by design: construction and renovation of health care facilities for patient safety and infection prevention. Infect Dis Clin North Am. 2016;30:713-728. http://dx.doi.org/10.1016/j.idc.2016.04.005.

3. Sehulster L, Chinn RY; CDC, HICPAC. Guidelines for environmental infection control in health-care facilities. recommendations of CDC and the healthcare infection control practices advisory committee (HICPAC). MMWR Recomm Rep. 2003;52:1-42.

4. Denton M, Wilcox MH, Parnell P, Green D, Keer V, Hawkey PM, et al. Role of environmental cleaning in controlling an outbreak of Acinetobacter baumannii on a neurosurgical intensive care unit. Intensive Crit Care Nurs. 2005;21:94-98.

5. Dharan S, Pittet D. Environmental controls in operating theatres. J Hosp Infect. 2002;51:79-84.

6. Mahida N, Clarke M, White G, Vaughan N, Boswell T. Outbreak of Enterobacter cloacae with New Delhi metallo- $\beta$-lactamase (NDM)-1: challenges in epidemiological investigation and environmental decontamination. J Hosp Infect. 2017;97:64-65. http://dx.doi.org/10.1016/j.jhin.2017.05.016.

7. Kim YA, Lee H, Lee K. Contamination of the hospital environmental by pathogenic bacteria and infection control. Korean J Nosocomial Infect Control. 2015;20:1-6.

8. Tablan OC, Anderson LJ, Besser R, Bridges C, Hajjeh R; CDC, et al. Guidelines for preventing healthcare associated pneumonia, 2003: recommendations of CDC and the healthcare infection 
control practices advisory committee. MMWR Recomm Rep. 2004;53:1-36.

9. Seto WH. Airborne transmission and precautions: facts and myths. J Hosp Infect. 2015;89:225-228. http://dx.doi.org/10.1016/ j.jhin.2014.11.005.

10. Weber DJ, Rutala WA. Understanding and preventing transmission of healthcare-associated pathogens due to the contaminated hospital environment. Infect Control Hosp Epidemiol. 2013;34:449-452. http://dx.doi.org/10.1086/670 223.

11. Muller MP, MacDougall C, Lim M; Ontario Agency for Health Protection and Promotion Public Health Ontario; Provincial Infectious Diseases Advisory Committee on Infection Prevention and Control; Provincial Infectious Diseases Advisory Committee on Infection Prevention and Control. Antimicrobial surfaces to prevent healthcare-associated infections: a systematic review. J Hosp Infect. 2016;92:7-13. http://dx.doi.org/ 10.1016/j.jhin.2015.09.008.

12. Healy M, Huong J, Bittner T, Lising M, Frye S, Raza S, et al. Microbial DNA typing by automated repetitive-sequencebased PCR. J Clin Microbiol. 2005;43:199-207.

13. Maiden MC, Jansen van Rensburg MJ, Bray JE, Earle SG, Ford SA, Jolley KA, et al. MLST revisited: the gene-by-gene approach to bacterial genomics. Nat Rev Microbiol. 2013;11:728-736. http://dx.doi.org/10.1038/nrmicro3093.

14. CDC. Standard operating procedure for PulseNet PFGE of Escherichia coli O157:H7, Escherichia coli non-O157 (STEC), Salmonella serotypes, Shigella sonnei and Shigella flexneri, [Internet]. Atlanta: CDC; 2013 [cited 2018 June 4]. Available from: https://www.cdc.gov/pulsenet/PDF/ecoli-shigella-salmonella-pfge-protocol-508c.pdf.

15. Moser SA, Box MJ, Patel M, Amaya M, Schelonka R, Waites KB. Multiple-locus variable-number tandem-repeat analysis of methicillin-resistant Staphylococcus aureus discriminates within USA pulsed-field gel electrophoresis types. J Hosp Infect. 2009;71:333-339. http://dx.doi.org/10.1016/j.jhin.2008.12.011.

16. Tenover FC, Arbeit RD, Goering RV. How to select and interpret molecular strain typing methods for epidemiological studies of bacterial infections: a review for healthcare epidemiologists. Molecular typing working group of the society for healthcare epidemiology of America. Infect Control Hosp Epidemiol. 1997;18:426-439.

17. Breathnach AS, Cubbon MD, Karunaharan RN, Pope CF, Planche TD. Multidrug-resistant Pseudomonas aeruginosa outbreaks in two hospitals: association with contaminated hospital wastewater systems. J Hosp Infect. 2012;82:19-24.

18. Garg SK, Mittal S, Kaur P. Dental unit waterline management: historical perspectives and current trends. J Investig Clin Dent. 2012;3:247-52. http://dx.doi.org/10.1111/j.2041-1626.2012. 00135.x.

19. Glorieux G, Neirynck N, Veys N, Vanholder R. Dialysis water and fluid purity: more than endotoxin. Nephrol Dial Transplant. 2012;27:4010-4021. http://dx.doi.org/10.1093/ndt/gfs306.

20. Oie S, Kamiya A, Yoneda I, Uchiyama K, Tsuchida M, Takai K, et al. Microbial contamination of dialysate and its prevention in haemodialysis units. J Hosp Infect. 2003;54:115-119.

21. Rioufol C, Devys C, Meunier G, Perraud M, Goullet D. Quantitative determination of endotoxins released by bacterial biofilms. J Hosp Infect. 1999;43:203-209.
22. Trautmann M, Zauser B, Wiedeck H, Buttenschön K, Marre R. Bacterial colonization and endotoxin contamination of intravenous infusion fluids. J Hosp Infect. 1997;37:225-236.

23. Peiró SA, Kulander L, Eriksson O. Quantitative determination of endotoxins on surgical gloves. J Hosp Infect. 1990;16:167-72.

24. Descours G, Cassier P, Forey F, Ginevra C, Etienne J, Lina G, et al. Evaluation of BMPA, MWY, GVPC and BCYE media for the isolation of Legionella species from respiratory samples. J Microbiol Methods. 2014;98:119-21. http://dx.doi.org/10.1016/ j.mimet.2014.01.001.

25. Pottage T, Macken S, Walker JT, Bennett AM. Methicillin-resistant Staphylococcus aureus is more resistant to vaporized hydrogen peroxide than commercial Geobacillus stearothermophilus biological indicators. J Hosp Infect. 2012;80: 41-45. http://dx.doi.org/10.1016/j.jhin.2011.11.001.

26. Winter S, Smith A, Lappin D, McDonagh G, Kirk B. Failure of non-vacuum steam sterilization processes for dental handpieces. J Hosp Infect. 2017;97:343-347. http://dx.doi.org/10.1016/j.jhin.2017.09.004.

27. CDC. Guideline for disinfection and sterilization in healthcare facilities [Internet]. Atlanta: CDC; 2008 [cited 2018 June 4]. Available from: https://www.cdc.gov/infectioncontrol/pdf/ guidelines/disinfection-guidelines.pdf.

28. Cattoir L, Vanzieleghem T, Florin L, Helleputte T, De Vos M, Verhasselt B, et al. Surveillance of endoscopes: comparison of different sampling techniques. Infect Control Hosp Epidemiol. 2017;38:1062-1069. http://dx.doi.org/10.1017/ice.2017.115.

29. Kovaleva J, Degener JE, van der Mei HC. Mimicking disinfection and drying of biofilms in contaminated endoscopes. J Hosp Infect. 2010;76:345-350. http://dx.doi.org/10.1016/j.jhin.2010. 07.008 .

30. ASGE Quality assurance in endoscopy committee; Petersen BT, Chennat J, Cohen J, Cotton PB, et al. Multisociety guideline on reprocessing flexible gastrointestinal endoscopes. Gastrointest Endosc. 2011;73:1075-1084. http://dx.doi.org/10.1016/j.gie. 2011.03.1183.

31. Marek A, Smith A, Peat M, Connell A, Gillespie I, Morrison P, et al. Endoscopy supply water and final rinse testing: five years of experience. J Hosp Infect. 2014;88:207-212. http://dx.doi.org/10.1016/j.jhin.2014.09.004.

32. Bashaw MA. Guideline implementation: processing flexible endoscopes. AORN J. 2016;104:225-236. http://dx.doi.org/ 10.1016/j.aorn.2016.06.018.

33. Felföldi T, Heéger Z, Vargha M, Márialigeti K. Detection of potentially pathogenic bacteria in the drinking water distribution system of a hospital in Hungary. Clin Microbiol Infect. 2010;16:89-92. http://dx.doi.org/10.1111/j.1469-0691.2009. 02795.x.

34. Tanner WD, VanDerslice JA, Toor D, Benson LS, Porucznik CA, Goel RK, Atkinson RM. Development and field evaluation of a method for detecting carbapenem-resistant bacteria in drinking water. Syst Appl Microbiol. 2015;38:351-357. doi: 10.1016/j.syapm.2015.03.010.

35. Barrie D. The provision of food and catering services in hospital. J Hosp Infect. 1996;33:13-33.

36. Rompré A, Servais P, Baudart J, de-Roubin MR, Laurent P. Detection and enumeration of coliforms in drinking water: cur- 
rent methods and emerging approaches. J Microbiol Methods. 2002;49:31-54.

37. Holý O, Forsythe S. Cronobacter spp. as emerging causes of healthcare-associated infection. J Hosp Infect. 2014;86: 169-177. http://dx.doi.org/10.1016/j.jhin.2013.09.011.

38. Hansen D, Blahout B, Benner D, Popp W. Environmental sampling of particulate matter and fungal spores during demolition of a building on a hospital area. J Hosp Infect. 2008; 70:259-264. http://dx.doi.org/10.1016/j.jhin.2008.07.010.

39. McLarnon NA, Edwards G, Burrow JG, Maclaren W, Aidoo KE, Hepher M. The efficiency of an air filtration system in the hospital ward. Int J Environ Health Res. 2006;16:313-317.

40. Vincent JH. Aerosol sampling: science, standards, instrumentation and applications. New York: John Wiley \& Sons; 2007. p473.

41. O'Brien D, Stevens N, Fitzgerald-Hughes D, Humphreys H. Effect of a novel air disinfection system on airborne micro-organisms in a hospital outpatient clinic. J Hosp Infect. 2012; 80:98-99. http://dx.doi.org/10.1016/j.jhin.2011.08.018.

42. Tammelin A, Ljungqvist B, Reinmüller B. Single-use surgical clothing system for reduction of airborne bacteria in the operating room. J Hosp Infect. 2013;84:245-247. http://dx.doi.org/10.1016/j.jhin.2013.03.007.

43. Shiomori T, Miyamoto H, Makishima K, Yoshida M, Fujiyoshi T, Udaka T, et al. Evaluation of bedmaking-related airborne and surface methicillin-resistant Staphylococcus aureus contamination. J Hosp Infect. 2002;50:30-35.

44. Chong MS, Lee K. Status of infection control in Jeju-area general hospitals. Korean J Clin Lab Sci. 2016;48:130-136. http://dx.doi.org//10.15324/kjcls.2016.48.2.130.

45. Lund BM, O'Brien SJ. Microbiological safety of food in hospitals and other healthcare settings. J Hosp Infect. 2009;73:109-120. http://dx.doi.org/10.1016/j.jhin.2009.05.017.

46. Tenover FC, Arbeit RD, Goering RV, Mickelsen PA, Murray BE, Persing DH, et al. Interpreting chromosomal DNA restriction patterns produced by pulsed-field gel electrophoresis: criteria for bacterial strain typing. J Clin Microbiol. 1995;33:2233-
2239.

47. Wu F, Della-Latta P. Molecular typing strategies. Semin Perinatol. 2002;26:357-366.

48. Bartley PB, Ben Zakour NL, Stanton-Cook M, Muguli R. Hospital-wide eradication of a nosocomial Legionella pneumophila serogroup 1 outbreak. Clin Infect Dis. 2016;62:273-279. http://dx.doi.org/10.1093/cid/civ870.

49. Beilenhoff U, Neumann CS, Rey JF, Biering H, Blum R, Schmidt $\mathrm{V}$, et al. ESGE-ESGENA guideline for quality assurance in reprocessing: microbiological surveillance testing in endoscopy. Endoscopy. 2007;39:175-181.

50. Arroyo MG, Ferreira AM, Frota OP, Rigotti MA, de Andrade D, Brizzotti NS, et al, Effectiveness of ATP bioluminescence assay for presumptive identification of microorganisms in hospital water sources. BMC Infect Dis. 2017;17:458. http://dx.doi.org/10.1186/s12879-017-2562-y.

51. Gillespie E, Sievert W, Swan M, Kaye C, Edridge I, Stuart RL. Adenosine triphosphate bioluminescence to validate decontamination of endoscopes. J Hosp Infect. 2017;97:353-356. http://dx.doi.org/10.1016/j.jhin.2017.05.020.

52. Spaun GO, Goers TA, Pierce RA, Cassera MA, Scovil S, Swanstrom LL. Use of flexible endoscopes for NOTES: sterilization or high-level disinfection? Surg Endosc. 2010;24: 1581-1588. http://dx.doi.org/10.1007/s00464-009-0815-6.

53. Tang JW, Noakes CJ, Nielsen PV, Eames I, Nicolle A, Li Y, et al. Observing and quantifying airflows in the infection control of aerosol- and airborne-transmitted diseases: an overview of approaches. J Hosp Infect. 2011;77:213-222. http://dx.doi.org/10.1016/j.jhin.2010.09.037.

54. Griffiths WD, Bennett A, Speight S, Parks S. Determining the performance of a commercial air purification system for reducing airborne contamination using model micro-organisms: a new test methodology. J Hosp Infect. 2005;61:242-247.

55. Shintani H, Taniai E, Miki A, Kurosu S, Hayashi F. Comparison of the collecting efficiency of microbiological air samplers. J Hosp Infect. 2004;56:42-48. 